\title{
Climate change and air pollution
}

\section{Effects on pollen allergy and other allergic respiratory diseases}

\begin{abstract}
Gennaro D’Amato ${ }^{1,2}$, Karl Christian Bergmann ${ }^{3}$, Lorenzo Cecchi ${ }^{4}$, Isabella Annesi-Maesano 5 , Alessandro Sanduzzi ${ }^{1}$, Gennaro Liccardi ${ }^{2}$, Carolina Vitale ${ }^{1}$, Anna Stanziola ${ }^{1}$, Maria D'Amato ${ }^{1}$

'Division of Pneumology, Department of Respiratory Diseases, High Speciality Hospital "V.Monaldi" Naples and University of Naples Federico II, Naples, Italy; ${ }^{2}$ Division of Respiratory and Allergic Diseases, Department of Respiratory Diseases, High Speciality Hospital A. Cardarelli, Naples, Italy; ${ }^{3}$ Allergie-Centrum-Charité, Universitätsmedizin Berlin, Germany; ${ }^{4}$ Allergology and Immunology Unit, Interdepartmental Centre of Bioclimatology, University of Florence, Italy / Allergology and Immunology Unit, Azienda Sanitaria Prato, Italy; ${ }^{5}$ Université Pierre et Marie Curie, Paris, France
\end{abstract}

\section{Summary}

The observational evidence indicates that recent regional changes in climate, particularly temperature increases, have already affected a diverse set of physical and biological systems in many parts of the world. Allergens patterns are also changing in response to climate change and air pollution can modify the allergenic potential of pollen grains especially in the presence of specific weather conditions.

Although genetic factors are important in the development of asthma and allergic diseases, their rising trend can be explained only by changes occurring in the environment and urban air pollution by motor vehicles has been indicated as one of the major risk factors responsible for this increase.

Despite some differences in the air pollution profile and decreasing trends of some key air pollutants, air quality is an important concern for public health in the cities throughout the world.

Due to climate change, air pollution patterns are changing in several urbanized areas of the world with a significant effect on respiratory health. The underlying mechanisms of all these interactions are not well known yet. The consequences on health vary from decreases in lung function to allergic diseases, new onset of diseases, and exacerbation of chronic respiratory diseases. In addition, it is important to recall that an individual's response to pollution exposure depends on the source and components of air pollution, as well as meteorological conditions. Indeed, some air pollution-related incidents with asthma aggravation do not depend only on the increased production of air pollution, but rather on atmospheric factors that favor the accumulation of air pollutants at ground level.

Associations between thunderstorms and asthma morbidity of pollinosis-affected people have also been identified in multiple locations around the world (Fig. 1).
A factor clouding the problem is that laboratory evaluations do not reflect what happens during natural exposition.

Considering these aspects, governments worldwide, international organizations, and cooperations such as the World Health Organization (WHO) and the European Health Policy of the European Union (EU) are facing a growing problem of the respiratory effects induced by gaseous and particulate pollutants arising from motor vehicle emissions.

Cite this as D'Amato G, Bergmann KC, Cecchi L, Annesi-Maesano I, Sanduzzi A, Liccardi G, Vitale C, Stanziola A, D'Amato M. Climate change and air pollution - Effects on pollen allergy and other allergic respiratory diseases. Allergo J Int 2014; 23: 17-23

DOI 10.1007/s40629-014-0003-7

$\begin{array}{ll}\text { Abbreviations } \\ \mathrm{BALF}^{2} & \text { Bronchoalveolar lavage fluid } \\ \mathrm{CO}_{2} & \text { Carbon dioxide } \\ \mathrm{DEP} & \text { Diesel exhaust particle } \\ \mathrm{EU} & \text { European Union } \\ \mathrm{GM}-\mathrm{CSF} & \begin{array}{l}\text { Granulocyte-macrophage } \\ \text { colony-stimulating factor }\end{array} \\ \mathrm{IL} & \text { Interleukin } \\ \mathrm{IPCC} & \begin{array}{l}\text { Intergovernmental Panel } \\ \text { on Climate Change }\end{array} \\ \mathrm{NAAQS} & \text { National Ambient Air Quality Standards } \\ \mathrm{O}_{3} & \text { Ozone } \\ \mathrm{PAH} & \text { Polycyclic aromatic hydrocarbons } \\ \mathrm{PM} & \text { Particulate matter } \\ \mathrm{SO}{ }_{2} & \text { Sulphur dioxide } \\ \text { UFPM } & \text { Ultrafine particulate matter } \\ \text { WHO } & \text { World Health Organization }\end{array}$

\section{Key words}

Air pollution - respiratory allergy airways hyperresponsiveness bronchial asthma - environment climate change
Submitted

May 29, 2012

Accepted

November 26, 2012

Online Version http://link.springer. com/ journal/40629 


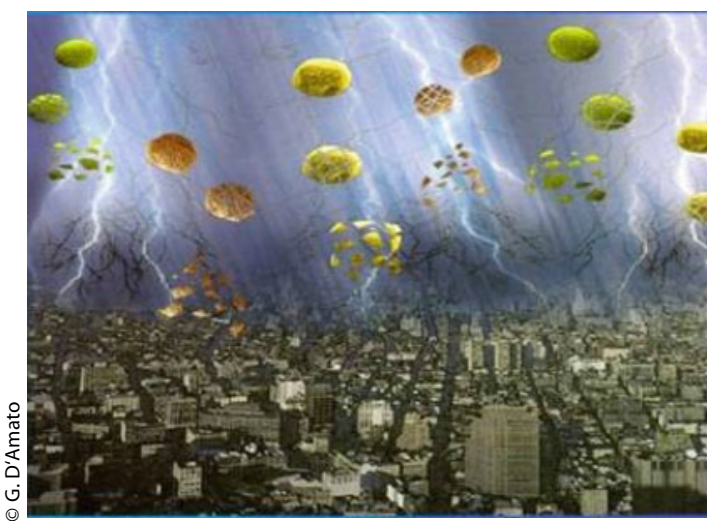

Fig. 1: Under wet conditions or during thunderstorms pollen grains may, after rupture by osmotic shock, release part of their cytoplasmic content into atmosphere.

\section{Introduction}

Global earth's temperature has markedly risen over the last 50 years due to the increase in greenhouse gas emissions, largely from anthropogenic sources. Changes are also occurring in the amount, intensity, frequency, and type of precipitation as well as in the increase of extreme events like heat waves, droughts, floods, thunderstorms, and hurricanes and these are a real and daunting problem [1-10].

The massive increase of air pollution due to economic and industrial growth during the last century led to a first order environmental problem in a large number of European and North American countries and is currently becoming an emerging problem in other regions of the world [1-43].

Air pollution is convincingly associated with many signs of asthma aggravation (increased bronchial hyper-responsiveness, visits to emergency departments, hospital admissions, increased medication use, etc.) [1, 8, 9, 16-19]. Moreover, sensitive techniques to analyze time-series data have shown that there are clear adverse effects on mortality rates due to current levels of air pollution [2, 3, 15].

Furthermore, several air pollutants, in particular carbon dioxide $\left(\mathrm{CO}_{2}\right)$ and ozone $\left(\mathrm{O}_{3}\right)$, are in the list of greenhouse gases which are involved in global warming [2-4, 7-9].

It is unlikely that global climate change can be explained without anthropogenic forcing. As stated in the Working Group I Report of the Intergovernmental Panel on Climate Change (IPCC) "most of the observed increase in globally averaged temperatures since the mid-20th century is very likely due to the observed increase in anthropogenic greenhouse gas concentrations" [2, 3]. A rapid rise in the number of hot days was also observed and severe meteorological events such as the 2003 and 2012 heat waves with temperatures up to $35^{\circ} \mathrm{C}$ and higher resulted in excess deaths in Europe $[5,6,20]$.
Moreover, climate scenarios for the next century predict that the warming will be associated with more frequent and more intense heat waves in wide areas of our planet with increased risk of wildfires and desertification. In urban areas, the effects are higher since climate change influences outdoor air pollution because of a strict correlation between generation and dispersion of air pollution and local patterns of temperature, wind, and precipitation.

Climate change has also led to water deprivation in certain areas often associated with population migration and the effects on health as a result of mass population movement.

Atopy and asthma are more prevalent in industrialized countries compared with undeveloped and less affluent countries. The effect on health of migration is age-related and time-dependent: younger persons and an increasing duration in the new environment increases the likelihood of developing atopy and asthma.

Climate changes will contribute to the development of atopy and respiratory diseases $[8,21]$.

A number of reports on time trends in allergic respiratory diseases and bronchial asthma have shown a substantial increase in the prevalence of these diseases since the early 1960 s $[1,12-14]$.

There is also a link between climate changes and air pollution and the individual's response to the source and components of air pollution and to climatic factors [4, 7-11]. Some air pollution-related episodes of rhinitis and asthma exacerbation are caused by climatic factors that favor the accumulation of air pollutants (e.g., $\mathrm{O}_{3}$ ) at ground level. However, the effects of air pollutants on lung function depend on the one hand on the environmental concentration and duration of the pollutants and on the other hand on the duration of exposure.

\section{Greenhouse gas emissions}

The key determinants of greenhouse gas emissions are energy production, house heating, transportation, agriculture and food production, and waste management. Attempts at mitigating climate change will need to address each of them. However, while there is some uncertainty about predicting future meteorological trends, whatever interventions may be put in place to ameliorate climate change, it is likely that the world will have more hot days, fewer frost days, and more periods of heavy rain and consequent flooding [2-4]. Paradoxically it is likely, that there will be more periods of drought. A huge increase in $\mathrm{CO}_{2}$ concentrations during the last two decades was measured. However, it is important to consider that after reduction of $\mathrm{CO}_{2}$ emissions and stabilization of atmospheric concentrations the surface air temperature will continuously and slowly rise for at least one century. 
The most abundant components of air pollution in urban areas are $\mathrm{NO}_{2}, \mathrm{O}_{3}$, and particulate matter (PM). $\mathrm{SO}_{2}$ is particularly abundant in industrial areas. More than $50 \%$ of the population of the United States are estimated to live in areas where levels of $\mathrm{NO}_{2}, \mathrm{O}_{3}, \mathrm{SO}_{2}$, and particulates exceed the current National Ambient Air Quality Standards (NAAQS), as monitored by the US Environmental Protection Agency $[2,3]$. With its particulate and gaseous emissions, road traffic contributes to air pollution in most urban areas. Although associations between air pollution and respiratory diseases are complex, recent epidemiological studies have led to an increased recognition of the emerging importance of traffic-related air pollution in both developed and less-developed countries [2, 3]. A number of experimental and epidemiological studies confirmed the negative effect of urban air pollution on human health and on allergic respiratory diseases $[1,7-11$, $21,22]$ and projections of climate variability suggest an increase in these effects during the next decades.

\section{Nitrogen dioxide}

Car, truck, and power plant exhausts are the most significant sources of outdoor $\mathrm{NO}_{2}$, which is a precursor of photochemical smog found in urban and industrial regions. Also, in conjunction with sunlight and hydrocarbons $\mathrm{NO}_{2}$ results in the production of $\mathrm{O}_{3}$. Like $\mathrm{O}_{3}, \mathrm{NO}_{2}$ is an oxidizing pollutant, but with a lower chemical reactivity than $\mathrm{O}_{3} . \mathrm{NO}_{2}$ exposure is associated with increased emergency room visits, wheezing, and medication use among children with asthma [23]. Controlled exposure studies on asthmatics have shown that $\mathrm{NO}_{2}$ can enhance the allergic response to inhaled allergens and $\mathrm{NO}_{2}$ concentrations in ambient air are also reportedly associated with cough, wheezing, and shortness of breath in atopic subjects [7-11,22].

\section{Ozone}

$\mathrm{O}_{3}$ is generated at ground level by photochemical reactions involving $\mathrm{NO}_{2}$, hydrocarbons, and UV radiation. $\mathrm{O}_{3}$ inhalation induces epithelial damage and consequent inflammatory responses in the upper and lower airways as shown by increased levels of inflammatory cells and mediators in nasal and bronchoalveolar lavage [23].

About $40-60 \%$ of inhaled $\mathrm{O}_{3}$ is absorbed in the nasal airways, the remainder reaching the lower airways. Exposure to increased atmospheric levels of $\mathrm{O}_{3}$ induces reduction of lung function, increased airway hyperreactivity to bronchoconstrictor agents, and is related to an increased risk of asthma exacerbations in asthmatic subjects [8-11, 22]. Epidemiologic studies have provided evidence that high ambient concentrations of this air pollutant are associated with an increased rate of asthma exacerba- tions, increased hospital admissions, and/or emergency department visits for respiratory diseases, including asthma. Furthermore, several studies suggest that $\mathrm{O}_{3}$ increases asthma morbidity by enhancing airway inflammation and epithelial permeability [7-11].

$\mathrm{O}_{3}$ exposure significantly increases levels of inflammatory cells (in particular neutrophils) and mediators such as Interleukin(IL)-6, IL-8, granulocyte-macrophage colony-stimulating factor (GM$\mathrm{CSF}$ ), and fibronectin in bronchoalveolar lavage fluid (BALF) of asthmatic subjects [21, 22].

It has been speculated for a long time that $\mathrm{O}_{3}$ and other pollutants may render allergic subjects more susceptible to the antigen they are sensitized [7-9]. It has been observed that the incidence of new diagnoses of asthma is associated with heavy exercise in communities with high concentrations of $\mathrm{O}_{3}$, thus, air pollution and outdoor exercise could contribute to the development of asthma $[21,22]$.

However, it is important to take into account that physical exercise in polluted areas results in greater deposition of air pollutants, including allergen-carrying particles, in the lower airways.

The acute health effects of exposure to ambient $\mathrm{O}_{3}$ have been examined in many geographical regions. Potential adverse effects include decrease in lung function, airway inflammation, symptoms of asth$\mathrm{ma}$, increases in hospitalization due to respiratory diseases, and excess mortality. $\mathrm{O}_{3}$ exposure has both a priming effect on allergen-induced responses and an intrinsic inflammatory action in the airways of allergic asthmatics [4, 9-11, 22].

In the long term, continuous exposure to high $\mathrm{O}_{3}$ levels impairs respiratory function and causes or exacerbates airway inflammation in healthy subjects and atopic asthmatics. At the population level, longterm exposure to $\mathrm{O}_{3}$ may reduce lung function in schoolchildren and adults and increase the prevalence of asthma and asthmatic symptoms [21, 22]. In addition, studies have shown that asthma can be exacerbated by $\mathrm{O}_{3}$, as measured by increased visits to emergency departments on days with higher levels of $\mathrm{O}_{3}$ and other pollutants [7-9].

\section{Traffic-related air pollution, particulate matter, and diesel exhaust particles}

There is evidence that living near high-traffic roads is associated with impaired respiratory health including asthma [16-19]. First, McConnell et al. [21] observed that the incidence of newly diagnosed asthma in children is associated with physical exercise in areas with high concentrations of $\mathrm{O}_{3}$ and PM. Since then, other prospective cohort studies have indicated that long-term exposure to traffic pollution could contribute to the development of asthmalike symptoms and allergic sensitization in children 


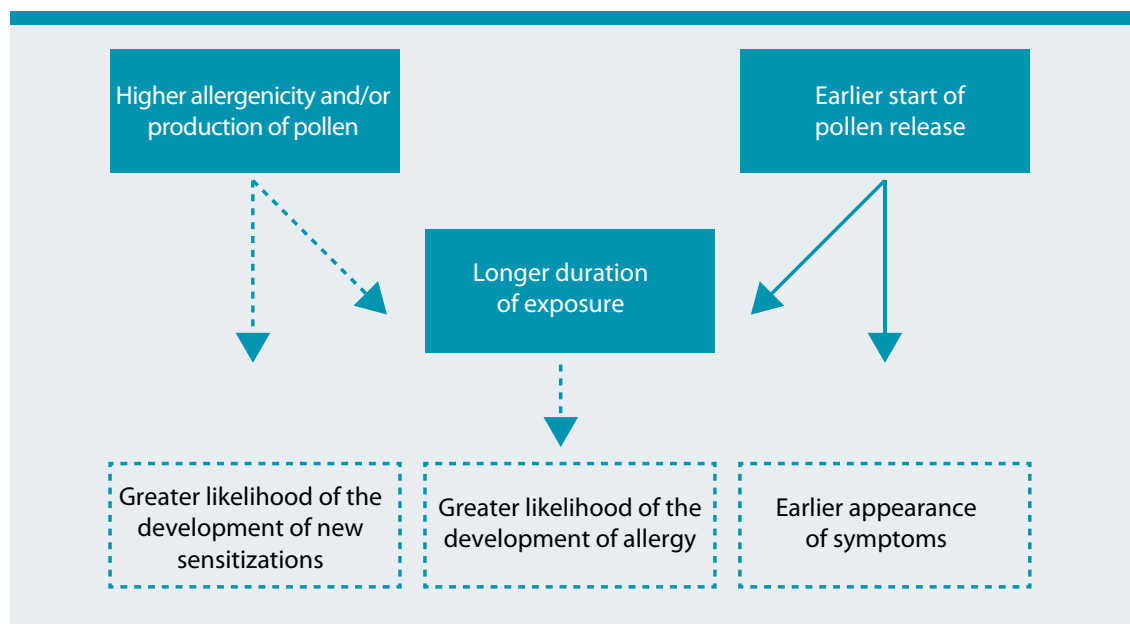

Fig. 2: Observed (solid arrows) and projected (dotted arrows) effects of climate change on pollen allergy

includes other components such as polycyclic aromatic hydrocarbons (PAH). DEPs account for up to $90 \%$ of airborne PM in the world's largest cities and are composed of fine $(2.5-0.1 \mu \mathrm{m})$ and ultrafine $(0.1 \mu \mathrm{m})$ particles, which can also can coalesce to form aggregates of varying sizes [25].

$\mathrm{PM}_{10}$ levels have been associated with early respiratory exacerbations in children with persistent asthma and with higher prevalence rates even after having considered the dispersion of the particles. Although there is compelling evidence that ambient air pollution exacerbates existing asthma, the link with the development of the asthma syndrome is still less well established, as few studies provide extensive exposure data. Researches have elucidated the mechanisms whereby fine particles induce adverse effects; they appear to affect the bal-

$[18,19]$. Potential long-term effects of traffic exhaust on the development of allergic sensitization were only assessed in the four European birth cohorts.

Long-term exposure to outdoor air pollutants had no association with sensitization in ten-year-old schoolchildren in Norway [24]. These studies, however, are flawed by the fact that no objective assessment of air pollution concentrations was available. Individual exposure was estimated by the distance from the highways.

$\mathrm{PM}$ is a mixture of organic and inorganic solid and liquid particles of different origins, size, and composition. It is a major component of urban air pollution and has the greatest effect on health. Penetration of the tracheobronchial area is related to particle size and the efficiency of airway defence mechanisms. Ultrafine particulate matter (UFPM), with diameters of $0.1 \mu \mathrm{m}$ or less, is a major component of vehicles' emissions. These particles accumulate into larger fine PM with a diameter of $\leq 2.5 \mathrm{~mm}\left(\mathrm{PM}_{2.5}\right.$, particulate matter with a diameter of $2.5 \mathrm{~mm}$ or less), within short distances from the point of release. $\mathrm{PM}_{10}$ consists of $\mathrm{PM}_{2.5}$ and larger particles of mainly crustal or biological origin including many aeroallergens. On the basis of epidemiological and laboratory studies, $\mathrm{PM}_{2.5}$ appears to be a more potent agent for the development of respiratory and cardiovascular disease compared with $\mathrm{PM}_{10}[16,17,25] . \mathrm{PM}_{10}$ can penetrate the lower airways, $\mathrm{PM}_{2.5}$, is thought to constitute a notable health risk since it can be inhaled more deeply into the lungs at the alveoli level. While human lung parenchyma retains $\mathrm{PM}_{2.5}$, particles larger than $5 \mu \mathrm{m}$. Particles smaller than $10 \mu \mathrm{m}$ reach the proximal airways only, where they are eliminated by mucociliary clearance if the airway mucosa is intact [7-9].

A large portion of urban PM originates from diesel engines, as diesel exhaust particles (DEPs) which ance between antioxidant pathways and airway inflammation. Gene polymorphisms involved in antioxidant pathways can modify responses to air pollution exposure. Acute exposure to diesel exhaust causes specific effects like irritation of nose and eyes, headache, lung function abnormalities, respiratory changes, fatigue, and nausea, while chronic exposure is associated with cough, sputum production, and diminished lung function [16-19,25].

Studies have demonstrated inflammation in the airways of healthy individuals after exposure to diesel exhaust and DEPs and elevated expression and concentrations of inflammatory mediators have similarly been observed in the respiratory tract after diesel exhaust and DEP exposure $[19,25]$. Even if an increased sensitivity of asthmatic individuals to the pro-inflammatory effects of DEPs has not been confirmed, some studies show a bigger effect of exposure to high-traffic roads in asthmatics compared to non asthmatic subjects, also accompanied by increases in levels of biomarkers of neutrophilic inflammation.

\section{Effect of climate change on allergic respiratory diseases}

A body of evidence suggests that major changes involving the atmosphere and the climate, including global warming induced by human activity, have an impact on the biosphere and human environment $[2,3]$.

Current knowledge on the worldwide effects of climate change on respiratory allergic diseases is provided by epidemiological and experimental studies on the relationship between asthma and environmental factors, like meteorological variables, airborne allergens, and air pollution.

Pollen allergy is frequently used to study the interrelationship between air pollution and allergic re- 
spiratory diseases, e.g., rhinitis and asthma (Fig. 2). Epidemiologic studies have demonstrated that urbanization, high levels of vehicle emissions, and westernized lifestyle are correlated to an increase in the frequency of pollen-induced respiratory allergy prevalent in people who live in urban areas compared to those who live in rural areas [8-11].

Meteorological factors (temperature, wind speed, humidity, thunderstorms etc.) along with their climatic regimes (warm or cold anomalies and dry or wet periods etc.) can affect both biological and chemical components of this interaction. In addition, by inducing airway inflammation, air pollution overcomes mucosal barrier priming allergen-induced responses.

Climate changes might induce negative effects on respiratory allergic diseases favoring the increased length and severity of pollen season, the higher occurrence of heavy precipitation events, and the increasing frequency of urban air pollution episodes.

However, the relationship between air pollution, pollen exposure, and respiratory allergy is based on an individual's response to air pollution, which depends on the source and components of the pollution as well as on climatic agents and genetic constitution.

\section{Thunderstorm-related allergic respiratory diseases and bronchial asthma in pollinosis subjects}

There are observations that thunderstorms occurring during pollen season can induce severe asthma attacks in pollinosis patients [20, 43-67].

According to current climate change scenarios, there will be an increase in intensity and frequency of heavy rainfall episodes, including thunderstorms, over the next few decades, which can be expected to be associated with an increase in the number and severity of asthma attacks both in adults and in children.

Associations between thunderstorms and asthma morbidity have been identified in multiple locations around the world [43-67]. So called "thunderstorm asthma" is characterized by asthma outbreaks possibly caused by the dispersion of more respirable allergenic particles derived from pollen and spores by osmotic rupture.

The most prominent hypotheses for thunderstorm-related asthma are linked with bioaerosols and involve the role of rainwater in promoting the release of respirable $\mathrm{PM}[45,57,61]$.

After hydratation and rupture by osmotic shock during the beginning of a thunderstorm, pollen grains may release in atmosphere part of their cytoplasmic content, including inhalable, allergen-carrying paucimicronic particles such as starch granules and other cytoplasmic components.

Thunderstorm-related asthma outbreaks have been described in various geographical zones such as Birmingham [43], London [48-50], and Melbourne [44].

Thunderstorm-related asthma was observed in Naples, Italy, on June 3 and 4, 2004 [60, 61], when six adults and one child received treatment in emergency departments. One patient was admitted to an intensive care unit for a very severe bronchial obstruction and acute respiratory insufficiency. All individuals were outdoors when the thunderstorm struck. In one severe case, a female sensitized only to Parietaria pollen allergen, soon began to show symptoms of intense dyspnoea, which gradually worsened. She was taken to hospital where she was intubated and given high intravenous doses of corticosteroids. She was discharged a few days later. This patient had previously suffered from seasonal asthma but had been asthma-free for the past few years and did not need continuous therapy. None of the other six persons regularly took anti-allergic and/or anti-asthma drugs. All seven patients were sensitized with allergic respiratory symptoms upon exposure to Parietaria pollen but were not sensitized to grasses. Parietaria is an Urticacea that is widespread in the Naples area of Italy with a spring and summer pollen season that is, in part, coexistent with that of grasses. During the thunderstorm, the concentration of airborne Parietaria pollen grains was particularly high with a peak of 144 grains $/ \mathrm{m}^{3}$ being recorded on June 3, 2004 [60, 61]. Air pollution levels for both gaseous and particulate components based on the hourly concentrations of $\mathrm{NO}_{2}$, $\mathrm{O}_{3}$, and respirable PM were not particularly high in Naples on June 3 and 4, 2004. Subjects with sensitization to Parietaria who were indoors in Naples with closed windows during the night between June 3 and 4, 2004, did not experience asthma attacks. No moulds or viruses were involved in the Naples epidemics. However, there is a risk of relapse of thunderstorm-related asthma [20,68].

In summary, the occurrence of these epidemics is closely linked to thunderstorm and they are limited to late spring and summer with high levels of airborne pollen grains. There is a close temporal association between the arrival of the thunderstorm, a major rise in the concentration of pollen grains, and the onset of epidemics. As a consequence, subjects affected by pollen allergy should be alert to the danger of being outdoors during a thunderstorm in the pollen season.

\section{Conclusions}

Exposure to air pollutants is largely beyond the control of individuals and requires action by public authorities at national, regional, and international levels. A multisectorial approach, engaging such relevant sectors as transport, housing, energy production, and industry is needed to develop and effec- 
tively implement long-term policies to reduce the risks of air pollution to health. In other words, strategies to reduce climate changes and air pollution are political in nature, but citizen, in particular health professionals, and societies must continuously and persistently raise their voices in the decision process to give strong support for clean policies on both national and international levels $[69,70]$.

\section{Prof. Gennaro D'Amato MD}

Division of Respiratory and Allergic Diseases,

Department of Respiratory Diseases

High Speciality Hospital A. Cardarelli

Via Rione Sirignano, 10

80121 Napoli, Italy

E-Mail: gdamatomail@gmail.com

Cite this as D'Amato G, Bergmann KC, Cecchi L, AnnesiMaesano I, Sanduzzi A, Liccardi G, Vitale C, Stanziola A, D'Amato M. Climate change and air pollution - Effects on pollen allergy and other allergic respiratory diseases. Allergo J Int 2014; 23: 17-23

DOI 10.1007/s40629-014-0003-7

\section{Conflict of interest}

The authors declare that they have no competing interests.

\section{References}

1. D'Amato G, Liccardi G, D'Amato M, Holgate ST. Environmental risk factors and allergic bronchial asthma. Clin Exp Allergy 2005; 35: 1113-24

2. Hegerl GC, Zwiers FW, Braconnot P, Gillett NP, Luo Y, Marengo JA et al. Understanding and attributing climate change. In Climate change 2007: the physical science basis. Contribution of the Working Group I to the Fourth Assessment Report of the Intergovernmental Panel on Climate Change. Edited by Solomon S, Qin D, Manning M, Chen Z, Marquis M, Averyt KB et al. Cambridge, UK and New York: Cambridge University Press; 2007: 663-746

3. Parry ML, Canziana OF, Palutikof JP, Adger N, Agarwal P, Agrawala $S$ et al. Technical summary. In Climate change 2007: impacts, adaptation, and vulnerabilities. Contribution of Working Group II to the Fourth Assessment Report of the Intergovernmental Panel on Climate Change. Edited by Parry ML, Canziana OF, Palutikof JP, van der Linden PJ, Hansen CE. Cambridge, UK: Cambridge University Press; 2007: 23-78

4. Shea KM, Truckner RT, Weber RW, Peden DB. Climate change and allergic disease. J Allergy Clin Immunol 2008; 122: 443-53

5. Stafoggia M, Forastiere F, Agostini D, Caranci N, de' Donato F, Demaria $\mathrm{M}$ et al. Factors affecting in-hospital heat-related mortality: a multi-city case-crossover analysis. J Epi Comm Health 2008; 62: 209-15

6. Michelozzi P, Accetta G, De Lario M, D'Ippoliti D, Marino C, Baccini M et al, PHEWE Collaborative Group. High temperature and hospitalizations for cardiovascular and respiratory causes in 12 european cities. Am J Respir Crit Care Med 2009; 179: 383-9

7. Ayres JG, Forberg B, Annesi-Maesano I, Dey R, Ebi KL, Helms PJ et al. Climate change and respiratory disease. European Respiratory Society position paper on behalf of the Environment \& Human Health Committee. Eur Respir J 2009; 34: 295-302
8. D'AG E. Outdoor air pollution, climate and allergic respiratory diseases: evidence of a link. Clin Exp Allergy 2002; 32: 1391-3

9. D'Amato G, Liccardi G. Allergenic pollen and urban air pollution in the mediterranean area. Allergy Clin Immunol Int 2003; 15 : 73-8

10. D'Amato G. Outdoor air pollution in urban areas and allergic respiratory diseases. Monaldi Arch Chest Dis 1999; 54 : 470-4

11. D'Amato G, Cecchi L. Effects of climate change on environmental factors in respiratory allergic diseases. Clin Exp Allergy 2008; 38: 1264-74

12. Burney PGJ. Evidence for an increase in atopic disease and possible causes. Clin Exp Allergy 1993; 23: 484-92

13. Woolcock AJ, Peat JK. Evidence for the increase in asthma worldwide. In "The rising trend in asthma". Ciba Foundation Symposium 206. Chichester, UK: John Wiley \& Sons; 1997: 122-39

14. The International Study of Asthma and Allergy in Childhood (ISAAC), Steering Committee. Worldwide variation in prevalence of symptoms of asthma, allergic rhinoconjunctivitis and atopic eczema. Lancet 1998; 351: 122532

15. Wilkinson P, Smith KR, Beevers S, Tonne C, Oreszczyn T. Energy, energy efficiency, and the built environment. Lancet 2007; 370: 1175-87

16. Sacks JD, Stanek LW, Luben TJ, Johns DO, Buckley BJ, Brown JS et al. Particulate matter-induced health effects: who is susceptible? Environ Health Perspect 2011; 119: 446-54

17. Ristovski ZD, Miljevic B, Surawski NC, Morawska L, Fong $\mathrm{KM}$, Goh F et al. Respiratory health effects of diesel particulate matter. Respirology 2012; 17: 201-12

18. Wjst M, Reitmar M, Dold S, Wulff A, Nicolai T, von Loeffelholz-Colberg E et al. Road traffic and adverse effects on respiratory health in children. BMJ 1993; 307: 596-600

19. Brăbäck L, Forsberg $B$. Does traffic exhaust contribute to the development of asthma and allergic sensitization in children: findings from recent cohort studies. Environ Health 2009; 8: 17

20. D'Amato G, Cecchi L, Annesi-Maesano I. A trans-disciplinary overview of case reports of thunderstorm-related asthma outbreaks and relapse. Eur Respir Rev 2012; 21: $82-7$

21. McConnell R, Berhane $\mathrm{K}$, Gilliland $\mathrm{F}$, London SJ, Islam $\mathrm{T}$, Gauderman WJ et al. Asthma in exercising children exposed to ozone: a cohort study. Lancet 2002; 359: 386-91

22. McDonnell WF, Abbey DE, Nishino N, Lebowitz MD. Longterm ambient ozone concentration and the incidence of asthma in nonsmoking adults: the AHSMOG Study. Environ Res 1999; 80: 110-21

23. Gauderman WJ, Avol E, Lurmann F, Kuenzli N, Gilliland F, Peters J et al. Childhood asthma and exposure to traffic and nitrogen dioxide. Epidemiology 2005; 16: 737-43

24. Oftedal B, Brunekreef B, Nystad W, Nafstad P. Residential outdoor air pollution and allergen sensitization in schoolchildren in Oslo, Norway. Clin Exp Allergy 2007; 37: 163240

25. Riedl M, Diaz Sanchez D. Biology of diesel exhaust effects on respiratory function. J Allergy Clin Immunol 2005; 115: 221-8

26. Laumbach RJ, Kipen HM. Respiratory health effects of air pollution: update on biomass smoke and traffic pollution. J Allergy Clin Immunol 2012; 129: 3-11

27. Bernstein JA, Alexis N, Barnes C, Leonard Bernstein I, Bernstein $\mathrm{JA}$, Nel A et al. Health effects of air pollution. J Allergy Clin Immunol 2004;114: 1116-1123

28. D'Amato G, Liccardi G, D'Amato M, Cazzola M. Outdoor air pollution, climatic changes and allergic bronchial asthma. Eur Resp J. 2002; 20: 763-76

29. Beggs PJ. Impacts of climate change on aeroallergens: past and future. Clin Exp Allergy 2004; 34: 1507-13 
30. D'Amato G. Urban air pollution and plant-derived respiratory allergy: a review. Clin Exp Allergy 2000; 30: 628-36

31. Ariano R, Canonica GW, Passalacqua G. Possible role of climate changes in variations in pollen seasons and allergic sensitizations during 27 years. Ann Allergy Asthma Immunol 2010; 104: 215-22

32. Cecchi L, Morabito M, Domeneghetti MP, Crisci A, Onorari $M$, Orlandini S. Long-distance transport of ragweed pollen as a potential cause of allergy in central Italy. Ann Allergy Asthma Immunol 2006; 96: 86-91

33. D'Amato G, Liccardi G. Pollen-related allergy in the European Mediterranean area. Clin Exp Allergy 1994; 24: 210-9

34. Melén E, Nyberg F, Lindgren CM, Berglind N, Zucchelli M, Nordling $E$ et al. Interactions between glutathione $S$ transferase $\mathrm{P} 1$, tumor necrosis factor, and traffic-related air pollution for development of childhood allergic disease. Environ Health Perspect 2008; 116: 1077-84

35. Morgenstern V, Zutavern A, Cyrys J, Brockow I, Gehring U, Koletzko $S$ et al. Respiratory health and individual estimated exposure to traffic-related air pollutants in a cohort of young children. Occup Environ Med 2007; 64: 8-16

36. Brauer M, Hoek G, Smit HA, de Jongste JC, Gerritsen J, Postma DS et al. Air pollution and development of asthma, allergy and infections in a birth cohort. Eur Respir J 2007; 29: 879-88

37. Traidl-Hoffmann C, Kasche A, Menzel A, Jakob T, Thiel M, Ring J et al. Impact of pollen on human health: more than allergen carriers? Int Arch Allergy Immunol 2003; 131: 1-13

38. D'Amato G, Cecchi L, Bonini S, Nunes C, Annesi-Maesano I, Behrendt $\mathrm{H}$ et al. Allergenic pollen and pollen allergy in Europe. Allergy 2007; 62: 976-90

39. D'Amato G, Spieksma FTM, Liccardi G, Jager S, Russo M, Kontoufili K et al. Pollen-related allergy in Europe. Position paper of the European Academy of Allergology and Clinical Immunology. Allergy 1998; 53: 567-78

40. Islam T, Gauderman WJ, Berhane K, McConnell R, Avol E, Peters JM et al. Relationship between air pollution, lung function and asthma in adolescents. Thorax 2007; 62: 957-63

41. D'Amato G, Liccardi G, D'Amato M, Cazzola M. Outdoor air pollution, climatic changes and allergic bronchial asthma. Eur Resp J 2002; 21: 12-26

42. D'Amato G, Ruffilli A, Ortolani C. Allergenic significance of Parietaria (pellitory-of-the-wall) pollen. In Allergenic Pollen and Pollinosis in Europe. Edited by D'Amato G, Spieksma F, Bonini S. Oxford: Blackwell Scientific Publications; 1991: 113-8

43. Packe GE, Ayres JG. Asthma outbreak during a thunderstorm. Lancet 1985; ii: 199-204

44. Bellomo R, Gigliotti P, Treloar A, Holmes P, Suphioglu C, Singh MB. Two consecutive thunderstorm associated epidemics of asthma in Melbourne. Med J Aust 1992; 156: 834-7

45. Knox RB. Grass pollen, thunderstorms and asthma. Clin Exp Allergy 1993; 23: 354-6

46. Murray V, Venables K, Laing-Morton T, Partridge M, Williams D. Epidemic of asthma possibly related to thunderstorms. BMJ 1994; 309: 131-2

47. Wallis DN, Davidson AC, Weilch J. Clinical and immunological characteristics of patients with thunderstorm asthma. Eur Respir J 1995; 8: 500

48. Thames Regions Accident and Emergency Trainer Association, Davidson AC, Emberlin J, Cook AD, Venables KM. A major outbreak of asthma associated with a thunderstorm. BMJ 1996; 312: 601-4

49. Celenza A, Fothergill J, Kupek E, Shaw RJ. Thunderstorms associated asthma: A detailed analysis of environmental factors. BMJ 1996; 312: 604-7
50. Venables KM, Allitt U, Collier CG, Emberlin J, Greig JB, Hardaker PJ et al. Thunderstorm-related asthma - epidemic 24/25 June 1994. Clin Exp Allergy 1997; 27: 725-36

51. Antò JM, Sunyer J. Thunderstorms: a risk factor for asthma attacks. Thorax 1997; 52: 669-70

52. Burney PGJ, Malmberg E, Chinn S, Jarvis D, Luczynska C, Lai $E$. The distribution of total and specific serum IgE in the European Community Respiratory Health Survey. J Allergy Clin Immunol 1997; 99: 314-22

53. Suphioglu $C$. Thunderstorm asthma due to grass pollen. Int Arch Allergy Immunol 1998; 116: 253-60

54. D'Amato G, Liccardi G, D'Amato M. Environmental risk factors (outdoor air pollution and climatic changes)and increased trend of respiratory allergy. J Invest Allergol Immunol. 2000; 10: 123-8

55. Girgis ST, Marks GB, Downs SH, Kolbe A, Car GN, Paton R. Thunderstormassociated asthma in an inland town in southeaster Australia. Who is at risk? Eur Respir J 2000; 16: 3-8

56. D'Amato G. Airborne paucimicronic allergen-carrying particles and seasonal respiratory allergy (Editorial). Allergy 2001; 56: 1109-11

57. Marks GB, Colquhoun JR, Girgis ST, Koski MH, Treloar AB, Hansen $P$ et al. Thunderstorm outflows preceding epidemics of asthma during spring and summer. Thorax 2001; 56: 468-71

58. Taylor PE, Hagan R, Valenta R, Glovsky MM. Release of allergens in respirable aerosols: $A$ link between grass pollen and asthma. J Allergy Clin Immunol 2002; 109: 51-6

59. Villeneuve PJ, Leech J, Bourque D. Frequency of emergency room visits for childhood asthma in Ottawa, Canada: the role of weather. Int J Biometeorol 2005; 50: 48-56

60. D'Amato G, Liccardi G, Gilder JA, Baldacci S, Viegi G. Thunderstorm-associated asthma in pollinosis patients. BMJ 2005, http://www.bmj.com/rapid-response/2011/10/30/thunderstorm-associated-asthmapollinosis-patients.

61. D'Amato G, Liccardi G, Frenguelli G. Thunderstorm asthma and pollen allergy. Allergy 2007; 62: 11-6

62. Haines A, Smith KR, Anderson D, Epstein R, McMichael AJ, Roberts I et al. Policies for accelerating access to clean energy, improving health, advancing development, and mitigating climate change. Lancet 2007; 370: 1264-81

63. Pulimood TB, Corden JM, Bryden C, Sharples L, Nasser $S M$. Epidemic asthma and the role of the fungal mold Alternaria alternate. J Allergy Clin Immunol 2007; 120: 610-7

64. D'Amato G, Cecchi L, Liccardi G. Thunderstorm-related asthma: not only grass pollen and spores. J Allergy Clin Immunol. 2008; 121: 537-8; author reply 538

65. Grundstein A, Sarnat SE, Klein M, Shepherd M, Naeher L, Mote T et al. Thunderstorm associated asthma in Atlanta, Georgia. Thorax 2008; 63: 659-60

66. Nasser SM, Pulimood TB. Allergens and thunderstorm asthma. Curr Allergy Asthma Rep 2009; 9: 384-90

67. Losappio L, Heffler E, Contento, Cannito C, Rolla G. Thunderstorm-related asthma epidemic owing to Olea Europea pollen sensitization. Allergy 2011; 66: 1510-1

68. D'Amato G, Corrado A, Cecchi L. A relapse of near-fatal thunderstorm-asthma in pregnancy. Eur Ann Allergy Clin Immunol. 2013; 45: 116-7

69. Pawankar R, Canonica GW, Holgate S, Lockey RF. WAO White Book on Allergy. Milwaukee: World Allergy Organization; 2011. www.worldallergy.org/UserFiles/file/WAOWhite-Book-on-Allergy_web.pdf.

70. D'Amato G, Holgate ST. The impact of air pollution on respiratory Health, European Respiratory Monograph, Volume 21. Sheffield UK, 2002 